\title{
MICROPROPAGAÇÃO DE GLOXÍNIA EM DIFERENTES CONCENTRAÇÕES DE NITRATO DE AMÔNIO E URÉIA
}

\author{
CHRYSTIANE BORGES FRÁGUAS ${ }^{1}$ \\ EDVAN ALVES CHAGAS ${ }^{1}$ \\ MANUELA MARTINS FERREIRA ${ }^{1}$ \\ JANICE GUEDES DE CARVALHO ${ }^{2}$ \\ MOACIR PASQUAL ${ }^{3}$
}

RESUMO - O elevado custo do nitrato de amônio, aliado
à dificuldade de aquisição do mesmo tem levado à realiza-
ção de trabalhos, no sentido de buscar alternativas para a
substituição dessa fonte de nitrogênio. Objetivou-se estudar
a viabilidade técnica da substituição do nitrato de amônio
por uréia, como fonte de nitrogênio no meio de cultura pa-
ra o cultivo in vitro de gloxínia. Segmentos nodais de plân-
tulas de gloxínia, já estabelecidas in vitro, foram inocula-
dos em meio de cultura $\mathrm{MS} 50 \%$, acrescido de 1 mg.L $\mathrm{L}^{-1}$ de
BAP, solidificado com $7 \mathrm{~g} . \mathrm{L}^{-1}$ de ágar, pH ajustado para
5,8 e autoclavado a $121^{\circ} \mathrm{C}$ e 1 atm por 20 minutos. Os tratamentos consistiram da substituição de $0,20,40,60,80$ e $100 \%$ do $\mathrm{NH}_{4} \mathrm{NO}_{3}$ por uréia, e o balanço de nitrogênio fornecido pelo meio MS não foi alterado. Os explantes foram mantidos por 120 dias em sala de crescimento com temperatura de $27 \pm 1^{\circ} \mathrm{C}$, fotoperíodo de 16 horas e intensidade luminosa de $32 \mu \mathrm{M} \cdot \mathrm{m}^{-2} \cdot \mathrm{s}^{-1}$. Com base nos resultados obtidos, pode-se concluir que a uréia não substitui o $\mathrm{NH}_{4} \mathrm{NO}_{3}$ do meio de cultura MS como fonte de nitrogênio no cultivo in vitro de gloxínia (Gloxinia speciosa Lodd.).

TERMOS PARA INDEXAÇÃO: Gloxinia speciosa, cultura de tecidos, fontes de nitrogênio.

\section{GLOXÍNIA MICROPROPAGATION IN DIFFERENT AMMONIUM NITRATE AND UREA CONCENTRATIONS}

\begin{abstract}
The high cost allied to the difficulty in the acquisition of the ammonium nitrate has been taking the accomplishment of works looking for an alternative for the substitution of this source of nitrogen. It was aimed at to study the technical viability of the substitution of the ammonium nitrate for urea, as source of nitrogen in the medium of culture for the culture in gloxinia "vitro". Gloxinia plantlets nodal segments were used, already established "in vitro", were inoculated in medium of culture MS $50 \%$, added of $1 \mathrm{mg} . \mathrm{L}^{-1}$ of BAP, solidified with 7 g... ${ }^{-1}$ of agar, $\mathrm{pH}$ was adjusted for 5,8 and sterilized to
\end{abstract}

INDEX TERMS: Gloxinia speciosa, tissue culture, sources of nitrogen.

\section{INTRODUÇÃO}

A demanda das plantas ornamentais e flores de corte dos países do Primeiro Mundo alcança U\$ 21 bilhões por ano, enquanto o Brasil responde por uma bai- $121^{\circ} \mathrm{C}$ and $1 \mathrm{~atm}$ for 20 minutes. The treatments consisted of the substitution of $0,20,40,60,80$ and $100 \%$ of $\mathrm{NH}_{4} \mathrm{NO}_{3}$ for urea, and the swinging of nitrogen supplied by the medium MS it was not altered. The explantes were maintained by 120 days in growth room with temperature of $27 \pm 1^{\circ} \mathrm{C}$, photoperiod of 16 hours and luminous intensity of $32 \mu \mathrm{M} . \mathrm{m}^{-2} . \mathrm{s}^{-1}$. From the obtained results it can be concluded that the urea doesn't substitute $\mathrm{NH}_{4} \mathrm{NO}_{3}$ in MS culture medium as nitrogen source in the culture of gloxinia (Gloxinia speciosa Lodd.).

\footnotetext{
1. Mestrando em Fitotecnia - Departamento de Agricultura, UNIVERSIDADE FEDERAL DE LAVRAS/UFLA - Caixa Postal 37 - 37200-000 - Lavras, MG.

2. Professora Titular do Departamento de Ciência do Solo/UFLA. janicegc@ufla.br

3. Professor Titular do Departamento de Agricultura/UFLA. mpasqual@ufla.br
} 
A gloxínia (Gloxinia speciosa) Lodd. é uma planta herbácea, ornamental, de vaso, cultivada pela beleza e exoticidade de suas flores. A maioria das espécies é de origem brasileira, desenvolvendo-se naturalmente nos picos rochosos da Serra do Mar, nos Estados do Paraná, São Paulo e Rio de Janeiro (Bittencourt et al., 1977).

A função do nitrogênio no crescimento e desenvolvimento das plantas é amplamente reconhecida. Entretanto, o efeito benéfico de ambas as formas de nitrogênio $\left(\mathrm{NO}_{3}{ }^{-}\right.$e $\left.\mathrm{NH}_{4}{ }^{+}\right)$não é bem entendido, já que essas e a quantidade de nitrogênio no meio de cultura têm grande influência na taxa de crescimento, morfologia e totipotência celular (Kirby et al., 1987). Além das formas inorgânicas de nitrogênio, podem ser fornecidas as formas orgânicas, as quais são prontamente assimiláveis pelas células vegetais. As formas específicas de nitrogênio orgânico incluem uréia, aminoácidos, poliaminas e ureídeos (Grothge, 1992).

Embora as plantas ornamentais sejam objeto de muita pesquisa, não existem trabalhos realizados com essas espécies na tentativa de se estudar fontes alternativas de nitrogênio no cultivo in vitro.

Wetherell \& Dougall (1976), trabalhando com explantes oriundos de pecíolo de cenoura, observaram que ácido glutâmico e uréia poderiam individualmente e parcialmente substituir o cloreto de amônio como suplemento para o nitrato de potássio. Polacco $(1976,1977)$ verificou o crescimento de células de soja em suspensão quando forneceu uréia ao meio, juntamente com adição de níquel. Incrementos no número de brotações também foram obtidos para algumas espécies ao serem cultivadas em meio de cultura com adição de uréia (Roy et al., 1996; Abha et al., 1992). Entretanto, segundo Kirby et al. (1987), culturas que foram estabelecidas em meio contendo uréia como única fonte de nitrogênio cresceram mais lentamente que células mantidas em meio de cultura contendo nitrato e amônio.

Por outro lado, o elevado custo, aliado à dificuldade na aquisição do nitrato de amônio, tem levado à realização de inúmeros trabalhos com o objetivo de buscar uma alternativa para a substituição dessa fonte de nitrogênio. Nesse contexto, objetivouse estudar a viabilidade técnica da substituição do nitrato de amônio por uréia, como fonte de nitrogênio no meio de cultura para o cultivo in vitro de gloxínia.

\section{MATERIAL E MÉTODOS}

Segmentos nodais contendo 2 gemas, excisados de plântulas de Gloxinia speciosa, com flores de coloração roxa, pré-estabelecidas in vitro, foram inoculados em meio de cultura MS (50\% da composição original) (Murashige \& Skoog, 1962), acrescido de $1 \mathrm{mg} . \mathrm{L}^{-1} \mathrm{de}$ BAP (benzilaminopurina), solidificado com 7 g.L. ${ }^{-1}$ de ágar, $\mathrm{pH}$ ajustado para 5,8 e autoclavado a $121^{\circ} \mathrm{C}$ e 1 atm por 20 minutos.

Os tratamentos consistiram da substituição de 0 , $20,40,60,80$ e $100 \%$ do $\mathrm{NH}_{4} \mathrm{NO}_{3}$ por uréia, e o balanço final de nitrogênio fornecido pelo meio de cultura MS não foi alterado.

$\mathrm{O}$ delineamento experimental utilizado foi o inteiramente casualizado com quatro repetições, sendo quatro tubos por repetição e os dados comparados pelo teste ' $\mathrm{t}$ ' ao nível de $5 \%$.

Após 120 dias em sala de crescimento com temperatura de $27 \pm 1^{\circ} \mathrm{C}$, fotoperíodo de 16 horas e intensidade luminosa de $32 \mu \mathrm{M} \cdot \mathrm{m}^{-2} \cdot \mathrm{s}^{-1}$, o experimento foi avaliado por meio do número de brotos, comprimento dos brotos $(\mathrm{cm})$ e peso da matéria fresca e seca da parte aérea $(\mathrm{g})$.

\section{RESULTADOS E DISCUSSÃO}

Apenas os explantes inoculados na ausência ou em meio de cultura contendo $20 \%$ de uréia sobreviveram. Observa-se com base na análise de variância que o efeito da uréia foi significativo para número de brotos (NB), comprimento dos brotos (CB) e peso da matéria fresca (PMFPA) e seca (PMSPA) da parte aérea (Tabela 1).

Os segmentos nodais inoculados em elevadas concentrações de uréia (substituição de 40, 60, 80 e $100 \%$ de nitrato de amônio) não sobreviveram, evidenciando que os explantes de gloxínia, por serem constituídos de tecidos mais tenros, são mais sensíveis ao efeito da uréia. Houve, portanto, um efeito fitotóxico. Para os tratamentos na ausência e na presença de $20 \%$ de uréia, foi possível a regeneração de plântulas. Geralmente, a utilização de uréia em concentrações ideais proporciona aumento no teor de clorofila, intensificando a coloração dos explantes e apresentando aspecto vigoroso (Grothge, 1992). Entretanto, no presente trabalho, observou-se diminuição na coloração típica das folhas de gloxínia quando cultivadas em meio contendo $20 \%$ de uréia, mostrando o início do efeito de fitotoxicidade proveniente da uréia. 
Melhor resultado para número de brotos $(1,87)$ foi obtido na ausência de uréia, isto é, na concentração padrão de $\mathrm{NH}_{4} \mathrm{NO}_{3}$ do meio de cultura MS (Figura 1). $\mathrm{Na}$ presença de $20 \%$ de uréia, embora tenha ocorrido a regeneração da plântula, não houve proliferação de brotos. Possivelmente, a concentração de $20 \%$ de uréia no meio de cultura inibiu o efeito da citocinina (BAP), não ocorrendo a multiplicação dos brotos.Esse resultado difere dos encontrados por Roy et al. (1996), que obtiveram aumento de 10 para 60 brotações por subcultura de Syzygium cumini Skeels, utilizando $100 \mathrm{mg} . \mathrm{L}^{-1}$ de uréia no meio de cultura. Abha et al. (1992) também obtiveram grande número de brotações diretas de Dendrobium wardianum Warner utilizando 2,5 ou 5 mg.L ${ }^{-1}$ de uréia no meio de cultura.

Maior ou menor efeito de fitotoxidade da uréia depende da concentração adicionada ao meio e do explante utilizado. Plantas lenhosas, geralmente, são mais resistentes e aproveitam melhor o nitrogênio pronta- mente disponibilizado na forma de uréia. Diferentemente, as espécies ornamentais, e que possuem tecidos mais tenros, são mais suscetíveis, principalmente quando cultivadas in vitro.

Maior comprimento dos brotos $(2,41 \mathrm{~cm})$ foi obtido em explantes cultivados na ausência de uréia (Figura 2). Na concentração de $20 \%$ de uréia adicionada ao meio de cultura, registrou-se um comprimento de brotos da ordem de 1,3 cm. Esse menor tamanho dos brotos ocorreu provavelmente devido ao efeito fitotóxico provocado pela uréia nos explantes. $\mathrm{O}$ trabalho com abacaxizeiro, constatou que as mudas se desenvolveram melhor quando cultivadas em meio de cultura MS (sólido ou líquido) na ausência de uréia.

Resultados contrários foram obtidos por Grothge (1992), quando observou efeito benéfico da adição de uréia no meio de cultura para o crescimento e desenvolvimento de explantes de Eucaliptus grandis Hill. ex Maiden.

TABELA 1 - Análise de variância para número de brotos (NB), comprimento de brotos (CB) e peso da matéria fresca (PMFPA) e seca (PMSPA) da parte aérea. Lavras, MG, 2002.

\begin{tabular}{cccccc}
\hline \multirow{2}{*}{ Fonte de variação } & \multirow{2}{*}{ GL } & \multicolumn{4}{c}{ Quadrados médios } \\
\cline { 3 - 6 } & & NB & CB & PMFPA & PMSPA \\
\cline { 3 - 6 } Uréia & 1 & $1,5312^{* *}$ & $2,4420^{* *}$ & $0,2620^{* *}$ & $0,0008^{* *}$ \\
Erro & 6 & 0,0637 & 0,1195 & 0,0415 & 0,000018 \\
\hline CV $(\%)$ & & 21,3 & 18,6 & 25,2 & 22,37 \\
\hline
\end{tabular}

**significativo ao nível de $1 \%$ de probabilidade pelo teste $\mathbf{F}$.

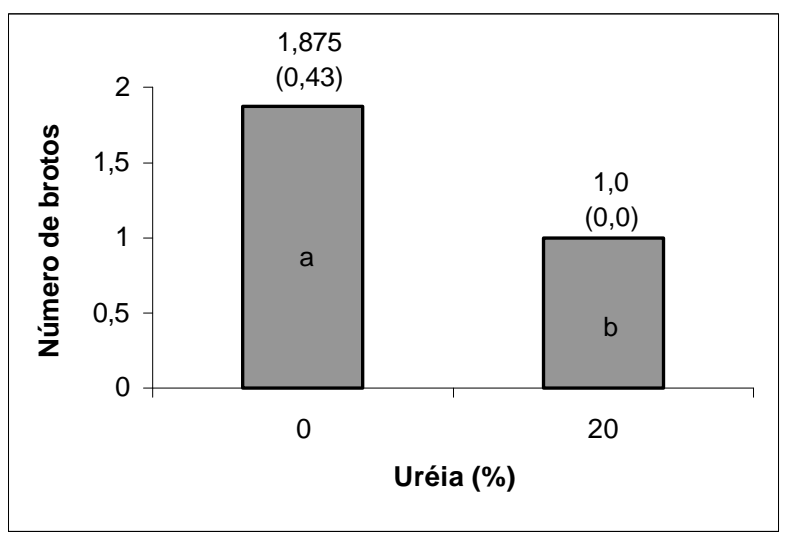

FIGURA 1 - Número médio e desvio-padrão de brotos em explantes de gloxínia micropropagados sob diferentes concentrações de uréia. Lavras-MG, 2002. 
O peso da matéria fresca da parte aérea comportou-se semelhantemente às demais variáveis, em que os explantes cultivados na ausência de uréia apresentaram os melhores resultados, seguidos do tratamento com $20 \%$ de uréia $(0,405$ e 0,043 g, respectivamente) (Figura 3). Também obteve melhor resultado de matéria fresca $(0,832 \mathrm{~g})$ na micropropagação de mudas de abacaxizeiro quando cultivados em meio MS na ausência de uréia. Porém, para o tratamento com $100 \%$ de uréia, substituindo o nitrato de amônio, obteve menor peso de matéria fresca $(0,35 \mathrm{~g})$. Contudo, esse tratamento não mostrou efeito fitotóxico.

Grothge (1992), trabalhando com clone G0694 de eucalipto, obteve maior peso de matéria fresca $(0,51$ g) utilizando $100 \mathrm{mg} . \mathrm{L}^{-1}$ de uréia. No entanto, quando utilizou concentrações maiores (200 e $300 \mathrm{mg} . \mathrm{L}^{-1}$ ), verificou decréscimo no peso de matéria fresca $(0,23$ e $0,21 \mathrm{~g}$, respectivamente), evidenciando que altas con- centrações de uréia no meio de cultura podem tornar-se fitotóxicas.

Maior peso da matéria seca da parte aérea $(0,0245 \mathrm{~g})$ também foi obtido quando os explantes foram cultivados em meio de cultura na ausência de uréia. Os explantes cultivados com $20 \%$ de uréia apresentaram menor massa $(0,0043 \mathrm{~g})$. Resultados semelhantes foram obtidos com mudas de abacaxizeiro quando cultivadas na ausência de uréia $(0,056 \mathrm{~g})$.

Também observou-se que é possível a obtenção de mudas de abacaxizeiro com a substituição de 20, 40, 60, 80 e $100 \%$ do nitrato de amônio por uréia, apesar de apresentarem resultados inferiores à medida que se eleva a concentração dessa no meio de cultura.

Grothge (1992) também observou que a matéria seca da parte aérea $(0,054 \mathrm{~g})$ do clone GO269 de eucalipto foi melhor quando cultivado em meio contendo $100 \mathrm{mg} . \mathrm{L}^{-1}$ de uréia. O mesmo clone apresentou menor

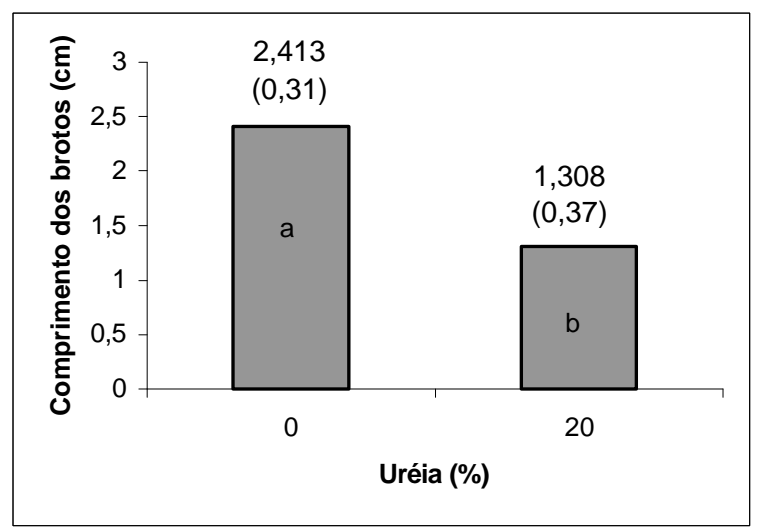

FIGURA 2 - Comprimento médio e desvio-padrão dos brotos em explantes de gloxínia micropropagados sob diferentes concentrações de uréia. Lavras- MG, 2002.

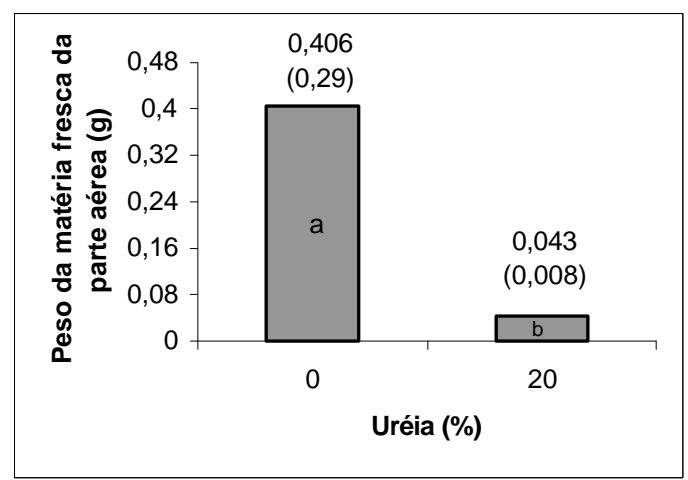

FIGURA 3 - Peso médio e desvio-padrão da matéria fresca da parte aérea em explantes de gloxínia micropropagados sob diferentes concentrações de uréia. Lavras-MG, 2002.

Ciênc. agrotec., Lavras. V.27, n.4, p.811-815, jul./ago., 2003 


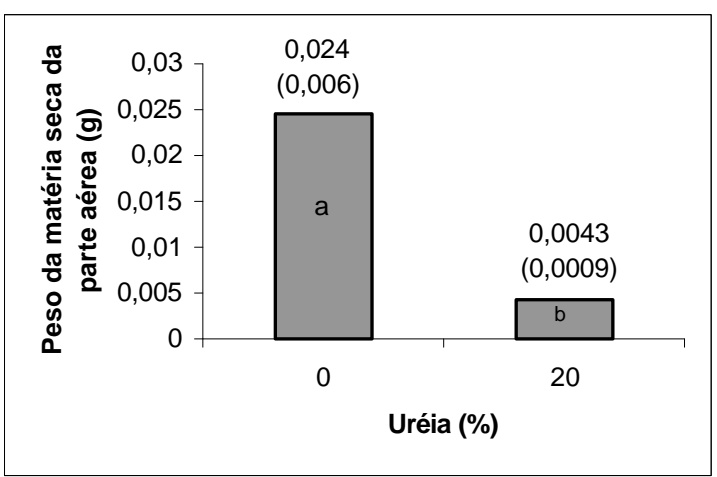

FIGURA 4 - Peso médio e desvio-padrão da matéria seca da parte aérea em explantes de gloxínia micropropagados sob diferentes concentrações de uréia. Lavras-MG, 2002.

peso de matéria seca da parte aérea $(0,041$ e $0,045 \mathrm{~g})$ quando cultivado em meio contendo 200 e $300 \mathrm{mg} . \mathrm{L}^{-1}$ de uréia, respectivamente.

Com base nos resultados obtidos, tornam-se necessários novos estudos que avaliem concentrações inferiores a $20 \mathrm{mg} . \mathrm{L}^{-1}$ de uréia no meio de cultura combinadas com concentrações de BAP superiores às utilizadas, a fim de eliminar o provável efeito inibitório da multiplicação causado pela uréia no presente trabalho.

\section{CONCLUSÃO}

Concentrações superiores a $20 \mathrm{mg} . \mathrm{L}^{-1}$ de uréia são tóxicas ao cultivo in vitro de gloxínia.

\section{REFERÊNCIAS BIBLIOGRÁFICAS}

ABHA, S.; PRAMOD, T.; SHARMA, A.; TANDON, P. In vitro culture of Dendrobium wardianum Warner: morphogenetic effects of some nitrogenous. Indian Journal of Plant Physiology, India, v. 35, n. 1, p. 80$85,1992$.

BITTENCOURT, J. F. N.; FERNANDES, P. D.; MATOS, J. R. Efeitos da aplicação de fertilizantes comerciais, via foliar, em gloxínia (Sinningia speciosa Lodd. Hiern). Anais da Escola Superior de Agricultura "Luiz de Queiroz", Piracicaba, v. 34, p. 121-126, 1977.

ORGANIZAÇÃO DAS NAÇÕES UNIDAS PARA A AGRICULTURA E ALIMENTAÇÃO. Disponível em: <http:\|www.fao.org>. Acesso em: 24 abr. 2001.
GROTHGE, M. T. Efeito de várias fontes de nitrogênio na multiplicação in vitro de clones de Eucalyptus grandis HILL ex MAIDEN. 1992. Dissertação (Mestrado) - Escola Superior de Agricultura Luiz de Queiroz, Piracicaba, 1992

KIRBY, E. G.; LEUSTEK, T.; LEE, M. S. Nitrogen Nutrition. In: BONGA, J. M.; DURZAN, D. J. (Eds.). Cell and Tissue Culture in Forestry. Dordrecht: Martinus Nijhoff, 1987. v. 1, p. 67-88.

MURASHIGE, T.; SKOOG, F. A revised medium for rapid growth and bioassays with tobacco tissue cultures. Physiologia Plantarum, Copenhagen, v. 15, n. 3, p. 473-497, 1962.

POLACCO, J. C. Nitrogen metabolism in soybean tissue culture. I: assimilation of urea. Plant Physiology, Lancaster, v. 58, p. 350-357, 1976.

POLACCO, J. C. Nitrogen metabolism in soybean tissue culture. II: urea utilization and urease synthesis require $\mathrm{Ni}^{+2}$. Plant Physiology, Lancaster, v. 59, p. 827830, 1977.

ROY, P. K.; RAHMAN, M. M.; ROY, S. K. Clonal propagation of Syzygium cumini L. through in vitro culture. Bangladesh Journal of Botany, Bangladesh, v. 25, n. 2, p. 159-164, 1996.

WETHERELL, D. F.; DOUGALL, D. K. Sources of nitrogen supporting growth and embryogenesis in cultured wild carrot tissue. Physiologia Plantarum, Copenhagen, v. 37, p. 97-103, 1976. 